Khyareh, M., M., \& Amini, H. (2021). Governance Quality, Entrepreneurship and Economic Growth. Journal of Competitiveness, 13(2), 41-64. https://doi.org/10.7441/joc.2021.02.03

\title{
Governance Quality, Entrepreneurship and Economic Growth
}

\section{- Mohsen Mohammadi Khyareh, Hadi Amini}

\begin{abstract}
Governance is a factor that affects new entrepreneurial activities and economic growth. However, the effectiveness of governance will vary depending on a country's development level and entrepreneurial motivation. The main goal of this study is to use global entrepreneurship monitor (GEM) data and to apply a three-stage least squares (3SLS) regression to investigate the impact of six governance indicators on the entrepreneurship-growth nexus in 64 countries during 2010-2018. In addition, this paper describes whether the impact of governance indicators varies according to the country's development stage. The results show that entrepreneurship and governance indicators have a significant impact on economic growth. However, depending on the development stage of the country, major differences can arise regarding the degree and nature of this relationship among countries. Specifically, the results show that entrepreneurship can promote economic growth in innovation-driven countries, but it cannot promote economic growth in factor- and efficiency-driven countries. In particular, the results show that opportunitydriven entrepreneurship (ODE) is only positively correlated with the economic growth of innovation-driven countries. In contrast, necessity-driven entrepreneurship (NDE) is negatively correlated with the economic growth of factor- and efficiency-driven countries. In addition, the survey results show that governance quality indicators contribute to entrepreneurial activities in the three groups of countries examined. This research contributes to the literature from a theoretical perspective (the use of good governance as an intermediary between entrepreneurship and growth) and a practical perspective (providing insights to improve the quality of governance to promote entrepreneurship and economic growth).
\end{abstract}

Keywords: entrepreneurship, governance quality, economic growth, competitiveness, GEM JEL Classification: O43, O47, L26

Received: October, 2020

1st Revision: March, 2021

Accepted: March, 2021

\section{INTRODUCTION}

The scientific consensus concurs that entrepreneurial activity is related to economic growth (Acs et al., 2018; Bosma et al., 2018; Carree \& Thurik, 2010; Doran et al., 2018; Dvouletý, 2018; Lepojevic et al., 2016; Urbano \& Aparicio, 2016; Valliere \& Peterson, 2009). However, certain empirical studies show that the role of entrepreneurship in economic growth varies with the diversity 
of entrepreneur types and also depends on the characteristics of the business environment in which economic growth occurs (Amorós et al., 2016; Aparicio et al., 2016; Simón-Moya et al., 2014). Furthermore, this relationship remains unclear (Carree \& Thurik, 2010), as a satisfactory model has not yet been obtained (Linán \& Fernández-Serrano, 2014; Valliere \& Peterson, 2009), and some challenges have not been examined. Therefore, in interpreting differences between countries, not only the entrepreneurial spirit should be considered, but also the type of entrepreneurship represented by a particular region (Baumol, 1996). Considering its relationship with economic growth and prosperity, entrepreneurship has aroused the interest of scholars and policymakers, not only to determine the factors that encourage entrepreneurship, but also to determine how different types of entrepreneurs contribute to the economic performance of different countries.

To broaden our understanding of the differences in entrepreneurship between countries, we conducted a literature review which includes institutional factors that may or may not hinder entrepreneurship (Aparicio et al., 2016; Belitski et al., 2016; Stenholm et al., 2013). Nevertheless, scholars have also indicated that entrepreneurship will only benefit countries with good governance. Kaufmann et al. (2017) pointed out that a solid legal framework, clear property rights, transparent and simple business creation procedures, as well as effective political and economic systems can encourage greater entrepreneurship. Recently, Youssef et al. (2018) argued that with a high level of innovation and institutional quality, the relationship between entrepreneurship and sustainable development can become very positive.

Before defining our objectives, the authors will summarize three main sets of issues. The first issue is the assumption of entrepreneurial productivity, which includes the recognition that entrepreneurship always has a positive effect (Audretsch, 2012), and the opposing position of some scholars regarding this proposition (Linán \& Fernández-Serrano, 2014; Valliere \& Peterson, 2009).

The second issue is based on the entrepreneurial activities of a country's economic development stage, which involves the dichotomy between researchers who defend enterprise creation to achieve economic goals in developing countries and researchers who oppose this position. Certain studies show that entrepreneurship has a positive impact on industrialized countries which can be measured by economic growth (Audretsch, 2012), while in developing countries it has a negative effect (Sautte, 2013; Van Stel et al., 2005; Wennekers et al. 2008).

The third issue is that entrepreneurial activities can have a direct or indirect impact on economic growth based on the quality of state institutions, indicating that some of these differences are caused by the specific institutional environment in which entrepreneurs operate (Bosma et al., 2018; Jimenez et al., 2015).

In view of these scientific debates, the authors have introduced the following research questions: (a) Is entrepreneurship related to economic growth? (B) Considering that some authors have described different effects according to the type of economy, should economic growth encourage entrepreneurship in developing countries? (C) Does the relationship between the development of economic growth and entrepreneurship depend on the governance quality of the country?

Based on the defined problems and the research questions raised, three objectives were 
determined: objective 1: To investigate the possible existence of factors related to entrepreneurial activities and economic growth. Objective 2: To study the potential differences between the economic impacts of entrepreneurial activities between economic activities. Objective 3: To explore the possible role of governance quality as a mediator of the entrepreneurship-growth nexus.

Our analysis is in a sense close to Aparicio et al. (2016), who also analyzed the institutional factors that encourage entrepreneurship to achieve higher economic growth. Differences from Aparicio et al. (2016) as well as some related research, however, can be outlined. First, these authors have contributed to the literature by handling formal institutions (quality of governance) in a completely different way. Governance quality is a complex phenomenon, and as such we considered six moderating variables which are considered particularly important in the entrepreneurship literature. Second, our sample is larger than the sample considered by Aparicio et al. (2016). The sample covers more countries (64 countries instead of 43), and more importantly, our analysis is less biased against developed countries, as many developing countries have in recent years begun to participate GEM projects. If we consider the GEM distinction between factor-driven, efficiency-driven, and innovation-driven countries, the sample of Aparicio et al. (2016) does not include factor-driven countries, while the factor-driven countries in our sample are $23 \%$; only seven countries (less than 16\%) in Aparicio et al are at the efficiency-driven stage, while $19 \%$ of the countries in our sample fall into this category; in contrast, $70 \%$ of the countries in the sample are in the innovation-driven phase, while in the sample of Aparicio et al. (2016) $40 \%$ of countries fit this category. This international dimension and the inclusion of countries from different economic environments provide us with sufficient institutional variability, which is strongly recommended in the analysis of institutional environmental impact studies (Franke \& Richey, 2010). The use of common methods facilitates comparisons and makes the results obtained in the international situation credible. In addition, GEM has also identified various types of entrepreneurship, a delineation which will help manipulate the dependent variables, which is also different from Aparicio et al. (2016).

After a brief review of the literature, in the following sections the authors will outline the assumptions and overall framework. Then we determine the variables and data for empirical analysis. Next we use panel regression to focus on adjusting the role of governance quality between entrepreneurship and economic growth. Finally, we discuss the results of the statistical analysis along with their implications.

\section{THEORETICAL BACKGROUND}

\subsection{Entrepreneurship and economic growth}

An analysis of the literature reflects the existence of a large number of studies on the relationship between entrepreneurship and economic growth, such as: (Bjørnskov \& Foss, 2016; Bosma et al., 2018; Stam et al., 2011; Valliere \& Peterson, 2009; Van Stel et al., 2005; Wennekers et al., 2008). Some studies believe that different types of entrepreneurship have different effects on economic growth. Other studies have shown that necessity-driven entrepreneurship (NDE) is more concentrated in the weakest economies, while opportunity-driven entrepreneurship (ODE) 
is more concentrated in advanced economies (Amorós et al., 2016; Larroulet \& Couyoumdjian, 2009). In addition, Aparicio et al. (2016) found a positive correlation between ODE and economic growth, which shows that NDE has no long-term impact on economic growth.

Statistically speaking, the impact of entrepreneurship may also vary according to the economic stage (Amorós et al., 2016; Urbano \& Aparicio, 2016; Wennekers et al., 2008). The U curve represents the negative (or ineffective) impact of entrepreneurship on underdeveloped economies and the positive impact on developed economies (Van Stel et al., 2005; Wennekers et al., 2008). In addition, some authors believe that entrepreneurship can drive growth, but what matters is the nature of entrepreneurship (Sautet, 2013; Van Stel et al., 2005). Meanwhile, other authors (Stam et al., 2011) found that entrepreneurship has no significant impact in high-income countries but has a significant positive impact in low-income countries. On the contrary, developing countries are more likely to be in the factor-driven and efficiency-driven stages, more likely to have more NDE, which has a limited impact on economic growth (Acs et al., 2008). Other studies used different types of entrepreneurship (opportunity/necessity). For example, Linán \& FernándezSerrano (2014) argue that rich countries provide more opportunities. Sautet (2013) also explained the change in the $\mathrm{U}$ curve from necessity (developing countries) to opportunity-entrepreneurship (usually developed countries).

Furthermore, the literature analysis on entrepreneurship emphasizes that the impact of the institutional environment on entrepreneurship varies according to entrepreneurial motivation (Simon-Moya et al., 2014; A morós et al., 2016, 2019). In these regards, many studies have examined the relationship between governance indicators and entrepreneurial activity (Amorós et al., 2019; Debus et al., 2017; Estrin et al., 2013; Rodríguez-Gulías et al., 2018). The results showed that each component of governance indicators has different effects based on the entrepreneur's motivation (opportunity or necessity). According to some studies (Amorós \& Stenholm, 2014; Amoróset al., 2019), poor governance quality can stimulate NDE and hinder ODE. In addition, a large amount of academic literature has developed models to illustrate how governance affects economic growth (Huynh \& Jacho-Chavez, 2009; Kaufman et al., 2017). Their results show a strong positive and statistically causal relationship between governance quality and per capita income. Recently, Fredström et al. (2020) argue that formal institutions with good governance quality will affect the productivity of entrepreneurs.

From the above, there are a lot of studies linking entrepreneurship and growth, and there are also studies on institutions and economic growth. Therefore, it makes sense to analyze the interaction between institutions (governance quality), entrepreneurship and growth in a unified framework. Most recent studies have used multi-stage analysis to model the relationship between the institution, entrepreneurship, and economic growth, so that the institution first affects entrepreneurship, and in the second stage, entrepreneurship affects the economic Growth (Acs et al., 2017; Acs et al., 2018; Bjørnskov \& Foss, 2012, 2016; Bosma et al., 2018; Urbano et al., 2019). One of the conceptual models for establishing this relationship is through the Coleman bathtub model (Bjørnskov \& Foss, 2016; Kim et al., 2016), as shown in Figure 1.

Coleman (1990) used the bathtub model to show how macro-level structures influence behaviors and performance at the micro-level. Entrepreneurship researchers have extended the model to examine the role of the institutional environment in encouraging entrepreneurial activities and 
the subsequent impact of entrepreneurial activities on economic growth (Bjørnskov \& Foss, 2016; Kim et al., 2016). Initially, institutions appeared at the macro level and defined the rules of the game. Institutional quality determines the behavior of entrepreneurs at the micro-level by encouraging the characteristics and intentions of entrepreneurs (Boudreaux et al., 2018; Nikolaev et al., 2018; Nyström, 2008) (path B in Figure 1). These entrepreneurial traits and intentions, such as opportunity recognition, entrepreneur self-efficacy, fear of failure, and social capital, in turn, affect entrepreneurs' entry and participation (Boudreaux \& Nikolaev, 2019; Boudreaux et al., 2018) (path C in Figure 1). Finally, overall, entrepreneurs' investment and participation in macroeconomic growth are listed as path $\mathrm{D}$ in Figure 1. Therefore, rather than only at the macro-level (path A in Figure 1) affecting entrepreneurial growth and economic growth (Bjørnskov \& Foss, 2016; Nyström, 2008), 'Coleman's bathtub model provides insights into how micro-foundations explain the role of institutions in economic growth through entrepreneurial channels.

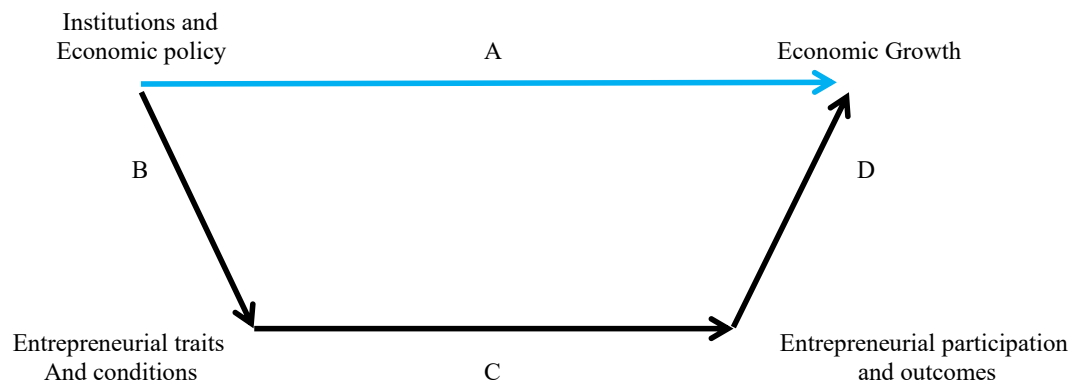

Fig. 1 - Diagram of a basic moderation model - Conceptual Diagram. Source: Coleman (1990)

The existing literature on this subject shows that governance quality can have a direct or indirect impact on economic growth. In addition, although the literature has inspired people in many ways, these studies are not without their limitations. First, the scope of previous researches is narrow, and most of them use governance quality to affect economic growth directly. Few studies use larger samples. The insights provided by case studies and economic models may be instructive, but their generality or usefulness for policymaking may be limited. In addition, existing research only describes whether institutions have theoretically affected economic growth or entrepreneurship. However, this topic requires further consideration to discern how different governance quality arrangements affect entrepreneurship. In order to address these limitations and contrast them with previous studies, this research focuses on testing the regulatory role of institutional activities and their impact on the relationship between entrepreneurship and economic growth. Therefore, there is the following proposed:

Hypothesis1: Governance has a positive influence on opportunity entrepreneurship.

Hypothesis2: Governance has a negative influence on necessity entrepreneurship.

Hypothesis3: Opportunity-driven entrepreneurship is positively associated with economic growth, but its impact differs by the level of economic development. 
Hypothesis4: Necessity-driven entrepreneurship is negatively associated with economic growth, but its impact differs by the level of economic development.

\section{RESEARCH OBJECTIVE, METHODOLOGY AND DATA}

This article examines whether the quality of national governance has eased the relationship between entrepreneurship and economic growth. First, we specify and estimate to follow the standard growth model of Aparicio et al. (2016) as a solid benchmark for research. Second, we directly introduce the measurement of entrepreneurship into the model. Under the assumption that governance quality affects entrepreneurship, the third step is to estimate the relationship between governance quality and entrepreneurial activities. In the fourth step, the link between governance quality and entrepreneurial activity is used to determine the impact of entrepreneurship on economic growth. Thus, the authors achieve this goal by simultaneously evaluating the impact of governance quality indicators on entrepreneurial activity measurement and per capita GDP growth in the three-stage least squares (3SLS) specification. The specification of a simple production function assumes that entrepreneurship is exogenous. However, on the one hand, the inverse causal relationship is at work, i.e., entrepreneurship and economic growth are linked recursively. On the other hand, entrepreneurship is also influenced by governance factors. Taking this into consideration, we specify the first equation to take this recursive structure explicitly into account, as well as the other variables that affect entrepreneurship. In its general form, this equation is written as:

$\mathrm{E}_{\mathrm{it}}=\mathrm{f}\left(\mathrm{GOV}_{\mathrm{it}}, \mathrm{X}_{\mathrm{it}}\right)$

Where $E_{i t}$ represents the entrepreneurial activities of country $i$ at time $t, G O V_{i t}$ is the vector of governance quality (GOV) factors, and $\mathrm{X}_{\mathrm{it}}$ is the vector of control variables affecting the entrepreneurial activities of country $i$ at time $t$. The vector of governance quality, including (1) voice and accountability (VA) (2) political stability and absence of violence (PS) (3) government effectiveness (GE) (4) regulatory quality (RQ) (5) the rule of law (RL) and (6) Corruption Control (CC). The vector of control variables is GDP growth (GDP), access to finance (FIN), and the time required to starting a new business (TB). The production function is a function of Cobb Douglass based on the entrepreneurial motivations (opportunity and necessity):

$$
\begin{aligned}
& \operatorname{GDP}_{i t}=\alpha O D E_{i t}^{\beta_{1}} K_{i t}^{\beta_{2}} T_{i t}^{\beta_{3}} \operatorname{INF}_{\text {it }}^{\beta_{4}} \mathrm{GC}_{\text {it }}^{\beta_{5}} \mathrm{GOV}_{\mathrm{it}}^{\beta_{6}} \mathrm{~L}_{\mathrm{it}}^{\beta_{7}} \\
& \mathrm{GDP}_{\mathrm{it}}=\alpha \mathrm{NDE}_{\mathrm{it}}^{\beta_{1}} \mathrm{~K}_{\mathrm{it}}^{\beta_{2}} \mathrm{~T}_{\mathrm{it}}^{\beta_{3}} \mathrm{INF}_{\mathrm{it}}^{\beta_{4}} \mathrm{GC}_{\mathrm{it}}^{\beta_{5}} \mathrm{GOV}_{\mathrm{it}}^{\beta_{6}} \mathrm{~L}_{\mathrm{it}}^{\beta_{7}}
\end{aligned}
$$

In equations (2) and (3) after Romer (1986), it is assumed that $\beta^{7}=1$. Then, manipulating two above equations by dividing them by Labor $\left(\mathrm{L}_{\mathrm{it}}\right)$, ensuring that the function has a constant scale rate of return, the equations as follows:

$$
\begin{aligned}
& \mathrm{GDP}_{\mathrm{it}} / \mathrm{L}_{\mathrm{it}}=\alpha \mathrm{ODE}_{\mathrm{it}}^{\beta_{1}} \mathrm{~K}_{\mathrm{it}}^{\beta_{2}} \mathrm{TR}_{\mathrm{it}}^{\beta_{3}} \mathrm{INF}_{\mathrm{it}}^{\beta_{4}} \mathrm{GC}_{\mathrm{it}}^{\beta_{5}} \mathrm{GOV}_{\mathrm{it}}^{\beta_{6}} \\
& \mathrm{GDP}_{\mathrm{it}} / \mathrm{L}_{\mathrm{it}}=\alpha \mathrm{NDE}_{\mathrm{it}}^{\beta_{1}} \mathrm{~K}_{\mathrm{it}}^{\beta_{2}} \mathrm{TR}_{\mathrm{it}}^{\beta_{3}} \mathrm{INF}_{\mathrm{it}}^{\beta_{4}} \mathrm{GC}_{\mathrm{it}}^{\beta_{5}} \mathrm{GOV}_{\mathrm{it}}^{\beta_{6}}
\end{aligned}
$$

Where $\mathrm{GDP}_{\mathrm{it}}$ is the economic output of country $\mathrm{i}$ at time $\mathrm{t}$, measured as the gross domestic product (GDP), $\mathrm{L}_{\mathrm{it}}$ represents the entire workforce (hence $\mathrm{GDP}_{\mathrm{it}} / \mathrm{L}_{\mathrm{it}}$ is labor productivity, 
used as a proxy for economic growth), $\mathrm{ODE}_{\mathrm{it}}$ and $\mathrm{NDE}_{\mathrm{it}}$ represent respectively, the degree of opportunity and necessity entrepreneurship in each country, $\mathrm{K}_{\mathrm{it}}$ is the amount of capital in country $\mathrm{i}, \mathrm{TR}_{\mathrm{it}}$ trade openness, $\mathrm{INF}_{\mathrm{it}}$ represents the inflation rate and $\mathrm{GC}_{\mathrm{it}}$ is the final government consumption.

Thus, this formally specifies that entrepreneurship contributes to the economic growth of countries. With Eq. (4) and (5), our approach is an extension of that chosen by Audretsch et al. (2008) and Aparicio et al. (2016), who emphasize that the impact of entrepreneurship on economic growth should take into account institutional factors; therefore, the authors focus on these two equations. We estimate this set of equations simultaneously using three-stage leastsquares regression (3SLS) to correct the simultaneity bias. Wooldridge (2010) proposed using the three-stage least squares (3SLS) method for the system of simultaneous equations. The advantage of 3SLS is that it is asymptotically more effective because it considers the correlation among the errors of each of the simultaneous equations of interest. The method also adjusts the weighting matrix for heteroskedasticity of the errors by estimating the coefficients within the generalized least squares (GLS) framework, the method outlined by Wooldridge (2010). This method is particularly suitable when over-identifying equations. In addition, if the system of equations is fully specified, the 3SLS method is more effective than the two-stage least squares (2SLS) method. The first dependent variable is necessity-driven entrepreneurship (NDE) and opportunity-driven entrepreneurship (ODE), which are the most famous indicators of global entrepreneurship monitor (GEM). The second dependent variable is the economic performance indicator, which is obtained by dividing constant GDP by the total labor force (L), one of the most famous economic growth indicators. The data sources to measure these dependent variables are the GEM and the world development indicator (WDI) of the world bank. The data on independent variables, specifically those of governance quality indicators, were obtained from the worldwide governance indicators (WGI). Meanwhile, data on the economic growth rate were obtained from the world development indicators (WDI) database. In terms of the measure of each variable, governance indicators range between -2.5 (low-quality governance) and 2.5 (highquality governance). For this paper, these indexes were rescaled from 0 to 5.

Given that different datasets were combined, this study uses panel data from 64 GEM member countries from 2010 to 2018 (Annex 1). Figures 2 and 3 show the average values of two types of opportunity and necessity entrepreneurial activities in resource, efficiency and innovationdriven countries. The rate of opportunity entrepreneurial activity in innovation-driven countries is higher than in resource- and efficiency-driven countries. The opposite applies to the necessity-driven entrepreneurial activity. Moreover, Figure 3 shows that countries with higher entrepreneurial spirit are usually countries with more developed governance quality factors: compared with factor-driven and efficiency-driven countries, innovation-driven countries occupy the top position.

Furthermore, the results obtained by the correlation matrix of the considered variables (the results not presented here but available on request) emphasize the correlation among the governance variables is high. Thus, we believe that multicollinearity is likely to be a problem in our models. We consider as a reference point the value of 0.70 . As we identify the presence of multicollinearity between the governance variables, we use six separation regression models (Models 1-6) for both types of entrepreneurship. 


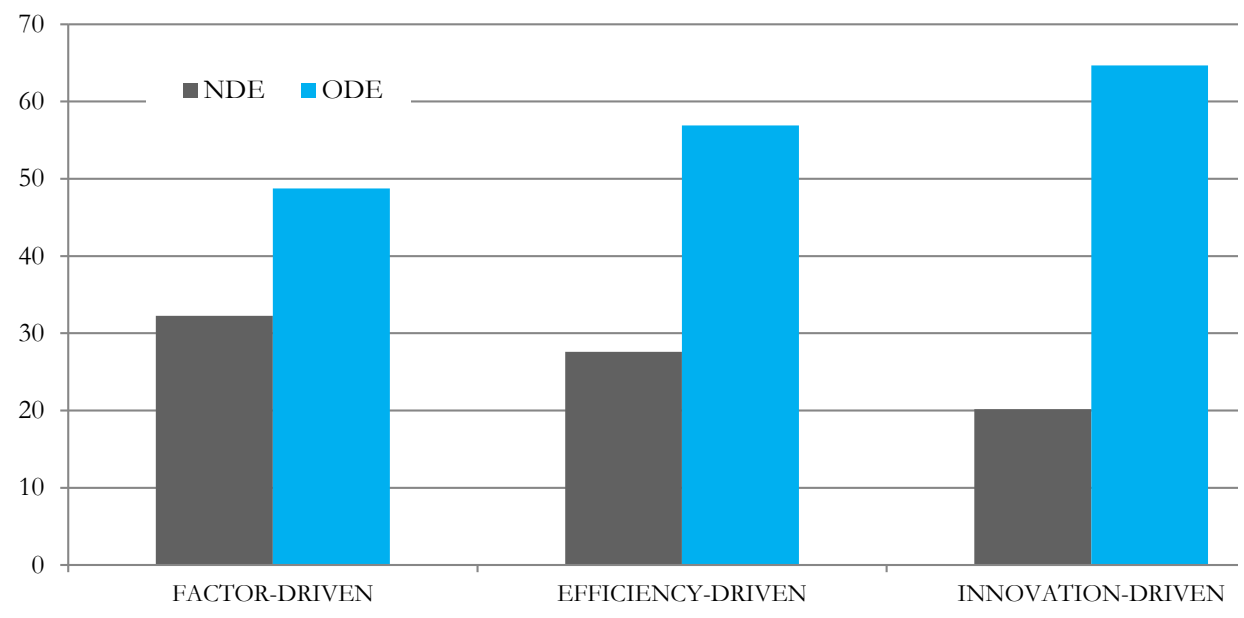

Fig. 2 - Average of entrepreneurial activities. Source: own research

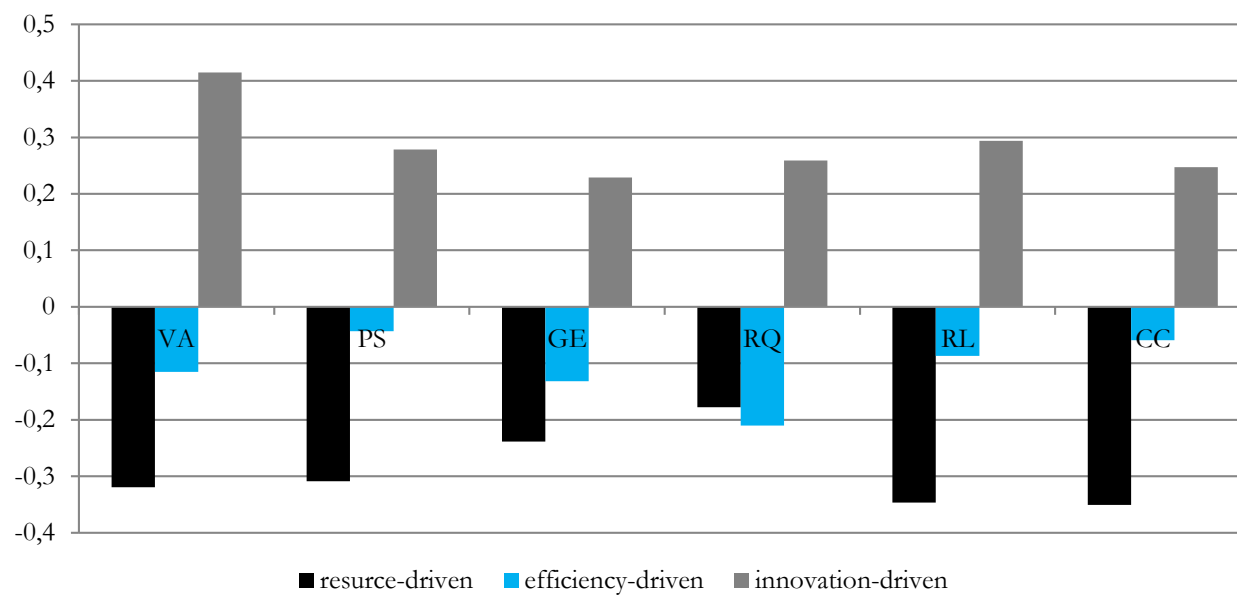

Fig. 3 - Average of governance quality indicator. Source: own research

\section{RESULTS AND DISCUSSION}

We estimate the system of equations jointly using 2SLS and 3SLS estimators (since the results are similar in both sign and economic significance, the results of 2SLS estimation not presented here but available on request). However, as the 3SLS estimators are consistent and asymptotically more efficient than single equation estimators; thus, 3SLS appears such an appropriate technique to produce better results. Tables 2-7 below provide the 3SLS findings linked to the empirical association among both forms of entrepreneurship, governance indicators (Models 1-6), and economic growth. Specifically, to analyze and compare the role of governance quality in entrepreneurship, we created six different models. Models 1-6 explore the impact of governance 
quality (the rule of law, government effectiveness, corruption control and political stability, regulatory quality, and voice and accountability) on entrepreneurial activities; controlling for GDP growth, access to finance, and the time required to Starting a new business (Equation (1)) and the relative importance of TEA to labor productivity (Equation (2)).

Tab. 1 - Estimating opportunity entrepreneurship and economic growth (factor-driven economies). Source: own research

\begin{tabular}{|c|c|c|c|c|c|c|}
\hline \multirow[b]{2}{*}{ Eq. (1) } & \multicolumn{6}{|c|}{ Dependent variable: ODE } \\
\hline & $\begin{array}{l}\text { Model } 1 \\
(\mathrm{VA})\end{array}$ & $\begin{array}{l}\text { Model } 2 \\
\text { (PS) }\end{array}$ & $\begin{array}{l}\text { Model } 3 \\
(\mathrm{GE})\end{array}$ & $\begin{array}{l}\text { Model } 4 \\
(\mathrm{RQ})\end{array}$ & $\begin{array}{l}\text { Model } 5 \\
(\mathrm{RL})\end{array}$ & $\begin{array}{l}\text { Model } 6 \\
(\mathrm{CC})\end{array}$ \\
\hline (VA) & $\begin{array}{l}0.31 * * * \\
(0.11)\end{array}$ & & & & & \\
\hline (PS) & & $\begin{array}{l}0.32^{* *} \\
(0.13)\end{array}$ & & & & \\
\hline$(\mathrm{GE})$ & & & $\begin{array}{l}0.221 \\
(0.126)\end{array}$ & & & \\
\hline (RQ) & & & & $\begin{array}{l}0.267 \\
(0.189)\end{array}$ & & \\
\hline$(\mathrm{RL})$ & & & & & $\begin{array}{l}0.27 * \\
(0.14)\end{array}$ & \\
\hline$(\mathrm{CC})$ & & & & & & $\begin{array}{l}0.252^{*} \\
(0.128)\end{array}$ \\
\hline$(\mathrm{GDP})$ & $0.03 *(0.01)$ & $\begin{array}{l}0.05^{* * *} \\
(0.01)\end{array}$ & $\begin{array}{l}0.08^{* *} \\
(0.03)\end{array}$ & $\begin{array}{l}0.033^{*} \\
(0.02)\end{array}$ & $\begin{array}{l}0.028^{*} \\
(0.01)\end{array}$ & $\begin{array}{l}0.04 * * * \\
(.012)\end{array}$ \\
\hline$(\mathrm{TB})$ & $\begin{array}{l}-0.33^{* * *} \\
(0.11)\end{array}$ & $\begin{array}{l}-0.29 * * \\
(0.11)\end{array}$ & $\begin{array}{l}-0.29 * * \\
(0.14)\end{array}$ & $\begin{array}{l}-0.43^{* * *} \\
(0.16)\end{array}$ & $\begin{array}{l}-0.42 * \\
(0.21)\end{array}$ & $\begin{array}{l}-0.57^{* *} \\
(0.22)\end{array}$ \\
\hline$(\mathrm{FIN})$ & $\begin{array}{l}0.327 * * \\
(0.135)\end{array}$ & $\begin{array}{l}0.492^{* *} \\
(0.213)\end{array}$ & $\begin{array}{l}0.543 \\
(0.297)\end{array}$ & $\begin{array}{l}0.47^{* * *} \\
(0.144)\end{array}$ & $\begin{array}{l}0.45^{* * *} \\
(0.137)\end{array}$ & $\begin{array}{l}0.486^{* *} \\
(0.212)\end{array}$ \\
\hline $\mathrm{R}^{2}$ & 0.890 & 0.893 & 0.898 & 0.886 & 0.885 & 0.871 \\
\hline Eq. (2) & 1 & 2 & 3 & 4 & 5 & 6 \\
\hline ODE & $\begin{array}{l}0.036 \\
(0.026)\end{array}$ & $\begin{array}{l}0.041 \\
(0.027)\end{array}$ & $\begin{array}{l}0.039 \\
(0.031)\end{array}$ & $\begin{array}{l}0.041 \\
(0.024)\end{array}$ & $\begin{array}{l}0.048 \\
(0.031)\end{array}$ & $\begin{array}{l}0.037 \\
(0.023)\end{array}$ \\
\hline NDE & - & - & - & - & - & - \\
\hline$(\mathrm{GCF})$ & $\begin{array}{l}0.163^{* *} \\
(0.058)\end{array}$ & $\begin{array}{c}0.171 * * \\
(0.064)\end{array}$ & $\begin{array}{l}0.142^{* * *} \\
(0.045)\end{array}$ & $\begin{array}{l}0.173^{* *} \\
(0.078)\end{array}$ & $\begin{array}{l}0.166^{* *} \\
(0.071)\end{array}$ & $\begin{array}{l}0.18^{* * *} \\
(0.058)\end{array}$ \\
\hline$(\mathrm{TR})$ & $\begin{array}{l}0.08^{* *} \\
(0.04)\end{array}$ & $\begin{array}{l}0.09 * * \\
(0.04)\end{array}$ & $\begin{array}{l}0.036^{* *} \\
(0.014)\end{array}$ & $\begin{array}{l}0.182^{* *} \\
(0.066)\end{array}$ & $\begin{array}{l}0.173 * * * \\
(0.051)\end{array}$ & $\begin{array}{l}0.138 * * \\
(0.052)\end{array}$ \\
\hline (INF) & $\begin{array}{l}-0.579 * \\
(0.323)\end{array}$ & $\begin{array}{l}-0.61 * * \\
(0.279)\end{array}$ & $\begin{array}{c}-0.427^{*} \\
(0.262)\end{array}$ & $\begin{array}{l}-0.523^{* *} \\
(0.298)\end{array}$ & $\begin{array}{l}-0.634 * * \\
(0.235)\end{array}$ & $\begin{array}{l}-0.447^{*} \\
(0.231)\end{array}$ \\
\hline
\end{tabular}




\begin{tabular}{|l|l|l|l|l|l|l|}
\hline$(\mathrm{GC})$ & $\begin{array}{l}0.251^{* *} \\
(0.114)\end{array}$ & $\begin{array}{l}0.238^{*} \\
(0.148)\end{array}$ & $\begin{array}{l}0.251^{* * *} \\
(0.161)\end{array}$ & $\begin{array}{l}0.287^{* *} \\
(0.109)\end{array}$ & $\begin{array}{l}0.421^{* *} \\
(0.167)\end{array}$ & $\begin{array}{l}0.432^{* *} \\
(0.183)\end{array}$ \\
\hline $\mathrm{R}^{2}$ & 0.941 & 0.925 & 0.914 & 0.935 & 0.928 & 0.912 \\
\hline
\end{tabular}

Notes: ***, **, * Significant at 1, 5, and 10 percent levels, respectively. $* * * p<0.01 ; *^{*} \mathrm{p}<0.05 ;{ }^{*} \mathrm{p}<0.1$. Robust standard errors are in parentheses under each coefficient.

From Table 1, in factor-driven economies, the effect of governance on opportunity entrepreneurship is positive for all estimated models except for Models 3 and 4 of the government effectiveness and regulatory quality, respectively. Opportunity entrepreneurship increased by one percent, resulting in a growth of 0.036 percent to 0.048 percent $(\mathrm{p}<0.05)$. In addition, Economic growth also provides an essential foundation for opportunity entrepreneurship in factor-driven countries.

Tab. 2 - Estimating necessity entrepreneurship and economic growth (factor-driven economies). Source: own research

\begin{tabular}{|c|c|c|c|c|c|c|}
\hline \multirow[b]{2}{*}{ Eq. (1) } & \multicolumn{6}{|l|}{ NEA } \\
\hline & $\begin{array}{l}\text { Model } 1 \\
(\mathrm{VA})\end{array}$ & $\begin{array}{l}\text { Model } 2 \\
\text { (PS) }\end{array}$ & $\begin{array}{l}\text { Model } 3 \\
\text { (GE) }\end{array}$ & $\begin{array}{l}\text { Model } 4 \\
\text { (RQ) }\end{array}$ & $\begin{array}{l}\text { Model } 5 \\
(\mathrm{RL})\end{array}$ & $\begin{array}{l}\text { Model } 6 \\
\text { (CC) }\end{array}$ \\
\hline (VA) & $\begin{array}{l}-0.24^{* *} \\
(0.11)\end{array}$ & & & & & \\
\hline (PS) & & $\begin{array}{l}-0.31 * \\
(0.19)\end{array}$ & & & & \\
\hline$(\mathrm{GE})$ & & & $\begin{array}{l}-0.245 \\
(0.123)\end{array}$ & & & \\
\hline$(\mathrm{RQ})$ & & & & $\begin{array}{l}-0.278 \\
(0.138)\end{array}$ & & \\
\hline (RL) & & & & & $\begin{array}{l}-0.31 * \\
(0.15) \\
\end{array}$ & \\
\hline$(\mathrm{CC})$ & & & & & & $\begin{array}{l}-0.21 * \\
(0.10)\end{array}$ \\
\hline (GDP) & $0.03(0.11)$ & $0.032(0.13)$ & $\begin{array}{l}0.005 \\
(0.04)\end{array}$ & $\begin{array}{l}0.001 \\
(0.02)\end{array}$ & $\begin{array}{l}0.003 \\
(0.01)\end{array}$ & $\begin{array}{l}0.004 \\
(.019)\end{array}$ \\
\hline$(\mathrm{TB})$ & $\begin{array}{l}-0.36^{* * *} \\
(0.11)\end{array}$ & $\begin{array}{l}-0.43^{*} \\
(0.22)\end{array}$ & $\begin{array}{l}-0.54^{* *} \\
(0.23)\end{array}$ & $\begin{array}{l}-0.46^{* *} \\
(0.21)\end{array}$ & $\begin{array}{l}-0.59 * * \\
(0.24)\end{array}$ & $\begin{array}{l}-0.36^{* * *} \\
(0.15)\end{array}$ \\
\hline$(\mathrm{FIN})$ & $\begin{array}{l}0.223 \\
(0.121)\end{array}$ & $\begin{array}{l}0.329 * * \\
(0.116)\end{array}$ & $\begin{array}{l}0.52^{* * *} \\
(0.212)\end{array}$ & $\begin{array}{l}0.289 \\
(0.147)\end{array}$ & $\begin{array}{l}0.427 \\
(0.27)\end{array}$ & $\begin{array}{l}0.531^{* *} \\
(0.248)\end{array}$ \\
\hline $\mathrm{R}^{2}$ & 0.881 & 0.879 & 0.891 & 0.893 & 0.881 & 0.869 \\
\hline Eq. (2) & 1 & 2 & 3 & 4 & 5 & 6 \\
\hline ODE & - & - & - & - & - & - \\
\hline NDE & $\begin{array}{l}-0.034^{* *} \\
(0.016)\end{array}$ & $\begin{array}{l}-0.04 * * * \\
(0.011)\end{array}$ & $\begin{array}{l}-0.03^{* *} \\
(0.014)\end{array}$ & $\begin{array}{l}-0.043^{*} \\
(0.019)\end{array}$ & $\begin{array}{l}-0.04 * \\
(0.02)\end{array}$ & $\begin{array}{l}-0.027^{* *} \\
(0.011)\end{array}$ \\
\hline
\end{tabular}




\begin{tabular}{|l|l|l|l|l|l|l|}
\hline$(\mathrm{GCF})$ & $\begin{array}{l}0.19^{* * *} \\
(0.062)\end{array}$ & $\begin{array}{l}0.173^{* *} \\
(0.074)\end{array}$ & $\begin{array}{l}0.161^{* *} \\
(0.055)\end{array}$ & $\begin{array}{l}0.143^{*} \\
(0.078)\end{array}$ & $\begin{array}{l}0.165^{* *} \\
(0.07)\end{array}$ & $\begin{array}{l}0.188^{* *} \\
(0.068)\end{array}$ \\
\hline \multirow{2}{*}{$(\mathrm{TR})$} & $\begin{array}{l}0.068^{* *} \\
(0.028)\end{array}$ & $\begin{array}{l}0.083^{* *} \\
(0.033)\end{array}$ & $\begin{array}{l}0.078^{* *} \\
(0.032)\end{array}$ & $\begin{array}{l}0.187^{* *} \\
(0.096)\end{array}$ & $\begin{array}{l}0.18^{* *} \\
(0.07)\end{array}$ & $\begin{array}{l}0.16^{* *} \\
(0.07)\end{array}$ \\
\hline \multirow{2}{*}{$(\mathrm{INF})$} & $-0.572^{* *}$ & $-0.531^{* *}$ & $-0.563^{* *}$ & $-0.651^{* *}$ & $-0.64 * * *$ & $-0.433^{*}$ \\
& $(0.224)$ & $(0.279)$ & $(0.262)$ & $(0.298)$ & $(0.23)$ & $(0.231)$ \\
\hline \multirow{2}{*}{$(\mathrm{GC})$} & $0.335^{* * *}$ & $0.333^{* * *}$ & $0.642^{* * *}$ & $0.367 * *$ & $0.421^{* *}$ & $0.239 * *$ \\
& $(0.122)$ & $(0.108)$ & $(0.261)$ & $(0.169)$ & $(0.177)$ & $(0.113)$ \\
\hline $\mathrm{R}^{2}$ & 0.903 & 0.922 & 0.906 & 0.913 & 0.942 & 0.911 \\
\hline
\end{tabular}

In factor-driven economies, the effect of governance on necessity entrepreneurship is negative for all estimated models except for Models 3 and 4 pertaining to the government effectiveness and regulatory quality, respectively. Gross capital formation increased by one percent, leading to growth from 0.143 percent to 0.19 percent $(p<0.1)$. Necessity entrepreneurship harms growth, and this entrepreneurial activity seems to decrease the growth of factor-driven countries. Meanwhile, economic growth does not seem to contribute necessity of entrepreneurship in factor-driven countries. Government consumption increased by one percent may, in turn, lead to growth from 0.333 percent to 0.642 percent $(\mathrm{p}<0.01)$. Economic openness increased by one percent, positively impacting economic growth by 0.068 percent to 0.187 percent $(\mathrm{p}<0.05)$. An inflation rate of one percent would decrease the growth by 0.433 percent to 0.651 percent $(\mathrm{p}<$ 0.05) (see Table 2).

Tab. 3 - Estimating opportunity entrepreneurship and economic growth (efficiency-driven economies). Source: own research

\begin{tabular}{|c|c|c|c|c|c|c|}
\hline \multirow[b]{2}{*}{ Eq. (1). } & \multicolumn{6}{|l|}{ ODE } \\
\hline & $\begin{array}{l}\text { Model } 1 \\
\text { (VA) }\end{array}$ & $\begin{array}{l}\text { Model } 2 \\
\text { (PS) }\end{array}$ & $\begin{array}{l}\text { Model } 3 \\
\text { (GE) }\end{array}$ & $\begin{array}{l}\text { Model } 4 \\
\text { (RQ) }\end{array}$ & $\begin{array}{l}\text { Model } 5 \\
(\mathrm{RL})\end{array}$ & $\begin{array}{l}\text { Model } 6 \\
\text { (CC) }\end{array}$ \\
\hline (VA) & $\begin{array}{l}0.211 * \\
(0.105)\end{array}$ & & & & & \\
\hline (PS) & & $\begin{array}{l}0.261^{* *} \\
(0.114)\end{array}$ & & & & \\
\hline (GE) & & & $\begin{array}{l}0.219 * * \\
(0.107)\end{array}$ & & & \\
\hline (RQ) & & & & $\begin{array}{l}0.253 \\
(0.138)\end{array}$ & & \\
\hline (RL) & & & & & $\begin{array}{l}0.262 * \\
(0.133)\end{array}$ & \\
\hline (CC) & & & & & & $\begin{array}{l}0.283^{* *} \\
(0.127)\end{array}$ \\
\hline (GDP) & $\begin{array}{l}0.039 * * \\
(0.016)\end{array}$ & $\begin{array}{l}0.036^{* *} \\
(0.014)\end{array}$ & $\begin{array}{l}0.042^{* *} \\
(0.015)\end{array}$ & $\begin{array}{l}0.022^{* *} \\
(0.009)\end{array}$ & $\begin{array}{l}0.018^{* * *} \\
(0.006)\end{array}$ & $\begin{array}{l}0.014 * \\
(.008)\end{array}$ \\
\hline
\end{tabular}




\begin{tabular}{|c|c|c|c|c|c|c|}
\hline (TB) & $\begin{array}{l}-0.312^{* *} \\
(0.138)\end{array}$ & $\begin{array}{l}-0.306^{* *} \\
(0.162)\end{array}$ & $\begin{array}{l}-0.242^{* *} \\
(0.137)\end{array}$ & $\begin{array}{l}-0.650 * \\
(0.364)\end{array}$ & $\begin{array}{l}-0.552^{* *} \\
(0.239)\end{array}$ & $\begin{array}{l}-0.756^{* * *} \\
(0.223)\end{array}$ \\
\hline$(\mathrm{FIN})$ & $\begin{array}{l}0.219^{* *} \\
(0.121)\end{array}$ & $\begin{array}{l}0.216^{* *} \\
(0.113)\end{array}$ & $\begin{array}{l}0.221 * * \\
(0.097)\end{array}$ & $\begin{array}{l}0.350^{* * *} \\
(0.144)\end{array}$ & $\begin{array}{l}0.371 * * \\
(0.167)\end{array}$ & $\begin{array}{l}0.451 * * \\
(0.233)\end{array}$ \\
\hline $\mathrm{R}^{2}$ & 0.887 & 0.885 & 0.892 & 0.894 & 0.891 & 0.879 \\
\hline Eq. (2) & 1 & 2 & 3 & 4 & 5 & 6 \\
\hline ODE & $\begin{array}{l}0.052 \\
(0.038)\end{array}$ & $\begin{array}{l}0.066 \\
(0.039)\end{array}$ & $\begin{array}{l}0.053 \\
(0.28)\end{array}$ & $\begin{array}{l}0.048 \\
(0.031)\end{array}$ & $\begin{array}{l}0.041 \\
(0.023)\end{array}$ & $\begin{array}{l}0.055 \\
(0.041)\end{array}$ \\
\hline NDE & - & - & - & - & - & - \\
\hline (GCF) & $\begin{array}{l}0.191 * * * \\
(0.032)\end{array}$ & $\begin{array}{l}0.189 * * * \\
(0.044)\end{array}$ & $\begin{array}{l}0.193 * * * \\
(0.045)\end{array}$ & $\begin{array}{l}0.188 * * \\
(0.078)\end{array}$ & $\begin{array}{l}0.175^{* *} \\
(0.071)\end{array}$ & $\begin{array}{l}0.196 * * * \\
(0.028)\end{array}$ \\
\hline (TR) & $\begin{array}{l}0.071^{* *} \\
(0.028)\end{array}$ & $\begin{array}{l}0.069 * * * \\
(0.023)\end{array}$ & $\begin{array}{l}0.059 * * \\
(0.025)\end{array}$ & $\begin{array}{l}0.195^{* * *} \\
(0.036)\end{array}$ & $\begin{array}{l}0.161 * * * \\
(0.041)\end{array}$ & $\begin{array}{l}0.142 * * * \\
(0.032)\end{array}$ \\
\hline$(\mathrm{INF})$ & $\begin{array}{l}-0.673^{* *} \\
(0.224)\end{array}$ & $\begin{array}{l}-0.689 * * \\
(0.279)\end{array}$ & $\begin{array}{c}-0.543^{*} \\
(0.262)\end{array}$ & $\begin{array}{l}-0.608 * * \\
(0.298)\end{array}$ & $\begin{array}{l}-0.611 * * \\
(0.235)\end{array}$ & $\begin{array}{l}-0.571 * * \\
(0.231)\end{array}$ \\
\hline$(\mathrm{GC})$ & $\begin{array}{l}0.431 * * * \\
(0.122)\end{array}$ & $\begin{array}{l}0.453 * * * \\
(0.148)\end{array}$ & $\begin{array}{l}0.264 * * \\
(0.121) \\
\end{array}$ & $\begin{array}{l}0.349 * * \\
(0.169)\end{array}$ & $\begin{array}{l}0.362^{* *} \\
(0.167)\end{array}$ & $\begin{array}{l}0.629 * * \\
(0.303)\end{array}$ \\
\hline $\mathrm{R}^{2}$ & 0.953 & 0.945 & 0.944 & 0.935 & 0.915 & 0.902 \\
\hline
\end{tabular}

Among efficiency-driven countries, except for Model 4 (RQ), as expected, governance indicators have a positive impact on opportunity entrepreneurship. Economic growth in efficiency-driven countries is tending to support opportunity-driven entrepreneurship activities. If economic growth increased by one percent, ODE increased by 0.014 percent to 0.042 percent $(\mathrm{p}<0.05)$. Meanwhile, the ODE doesn't seem to contribute to economic growth in these countries (Table 3).

Tab. 4 - Estimating necessity entrepreneurship and economic growth (efficiency-driven economies). Source: own research

\begin{tabular}{|c|c|c|c|c|c|c|}
\hline \multirow[b]{2}{*}{ Eq. (1). } & \multicolumn{6}{|l|}{ NDE } \\
\hline & $\begin{array}{l}\text { Model } 1 \\
\text { (VA) }\end{array}$ & $\begin{array}{l}\text { Model } 2 \\
\text { (PS) }\end{array}$ & $\begin{array}{l}\text { Model } 3 \\
\text { (GE) }\end{array}$ & $\begin{array}{l}\text { Model } 4 \\
\text { (RQ) }\end{array}$ & $\begin{array}{l}\text { Model } 5 \\
(\mathrm{RL})\end{array}$ & $\begin{array}{l}\text { Model } 6 \\
\text { (CC) }\end{array}$ \\
\hline$(\mathrm{VA})$ & $\begin{array}{l}-0.149 * * \\
(0.121)\end{array}$ & & & & & \\
\hline (PS) & & $\begin{array}{l}-0.204^{* *} \\
(0.092)\end{array}$ & & & & \\
\hline$(\mathrm{GE})$ & & & $\begin{array}{l}-0.165^{* *} \\
(0.063)\end{array}$ & & & \\
\hline (RQ) & & & & $\begin{array}{l}-0.216 \\
(0.134)\end{array}$ & & \\
\hline$(\mathrm{RL})$ & & & & & $\begin{array}{l}-0.159 * * \\
(0.121)\end{array}$ & \\
\hline
\end{tabular}




\begin{tabular}{|c|c|c|c|c|c|c|}
\hline (CC) & & & & & & $\begin{array}{l}-0.161 * \\
(0.083)\end{array}$ \\
\hline (GDP) & $\begin{array}{l}0.0021 \\
(0.011)\end{array}$ & $\begin{array}{l}0.023 \\
(0.014)\end{array}$ & $\begin{array}{l}0.0028 \\
(0.012)\end{array}$ & $\begin{array}{l}0.0031 \\
(0.015)\end{array}$ & $\begin{array}{l}0.0026 \\
(0.009)\end{array}$ & $\begin{array}{l}0.0029 \\
(0.014)\end{array}$ \\
\hline (TB) & $\begin{array}{l}-0.322^{* *} \\
(0.117)\end{array}$ & $\begin{array}{l}-0.412^{*} \\
(0.209)\end{array}$ & $\begin{array}{l}-0.433^{* * *} \\
(0.122)\end{array}$ & $\begin{array}{c}-0.541 * \\
(0.311)\end{array}$ & $\begin{array}{l}-0.481^{*} \\
(0.245)\end{array}$ & $\begin{array}{l}-0.421^{*} \\
(0.208)\end{array}$ \\
\hline$(\mathrm{FIN})$ & $\begin{array}{l}0.221^{*} \\
(0.123)\end{array}$ & $\begin{array}{l}0.356^{* *} \\
(0.143)\end{array}$ & $\begin{array}{l}0.432 * * \\
(0.167)\end{array}$ & $\begin{array}{l}0.372 * * \\
(0.151)\end{array}$ & $\begin{array}{l}0.337 * * \\
(0.156)\end{array}$ & $\begin{array}{l}0.458^{* *} \\
(0.248)\end{array}$ \\
\hline $\mathrm{R}^{2}$ & 0.891 & 0.883 & 0.887 & 0.932 & 0.901 & 0.878 \\
\hline Eq. (2) & 1 & 2 & 3 & 4 & 5 & 6 \\
\hline OEA & - & - & - & - & - & - \\
\hline NEA & $\begin{array}{l}-0.024^{* *} \\
(0.009)\end{array}$ & $\begin{array}{l}-0.029 * \\
(0.017)\end{array}$ & $\begin{array}{l}-0.031^{*} \\
(0.018)\end{array}$ & $\begin{array}{l}-0.029 * * * \\
(0.012)\end{array}$ & $\begin{array}{l}-0.019 * * \\
(0.009)\end{array}$ & $\begin{array}{l}-0.021 * * \\
(0.011)\end{array}$ \\
\hline (GCF) & $\begin{array}{l}0.145^{* * *} \\
(0.025)\end{array}$ & $\begin{array}{l}0.119 * * * \\
(0.026) \\
\end{array}$ & $\begin{array}{l}0.187 * * * \\
(0.037) \\
\end{array}$ & $\begin{array}{l}0.162^{* * *} \\
(0.045)\end{array}$ & $\begin{array}{l}0.189 * * * \\
(0.052)\end{array}$ & $\begin{array}{l}0.152^{* * *} \\
(0.041)\end{array}$ \\
\hline (TR) & $\begin{array}{l}0.059 * * \\
(0.021)\end{array}$ & $\begin{array}{l}0.078^{* *} \\
(0.029)\end{array}$ & $\begin{array}{l}0.066^{* *} \\
(0.025)\end{array}$ & $\begin{array}{l}0.171 * * * \\
(0.032)\end{array}$ & $\begin{array}{l}0.159 * * * \\
(0.041)\end{array}$ & $\begin{array}{l}0.162^{* * *} \\
(0.033)\end{array}$ \\
\hline$(\mathrm{INF})$ & $\begin{array}{l}-0.445^{* *} \\
(0.133)\end{array}$ & $\begin{array}{l}-0.461 * * \\
(0.221)\end{array}$ & $\begin{array}{l}-0.501 * \\
(0.362)\end{array}$ & $\begin{array}{l}-0.479 * * \\
(0.218)\end{array}$ & $\begin{array}{l}-0.331 * * \\
(0.139)\end{array}$ & $\begin{array}{l}-0.518^{*} \\
(0.316)\end{array}$ \\
\hline (GC) & $\begin{array}{l}0.475^{\text {*** }} \\
(0.122)\end{array}$ & $\begin{array}{l}0.439 * * * \\
(0.108)\end{array}$ & $\begin{array}{l}0.542^{* *} \\
(0.261)\end{array}$ & $\begin{array}{l}0.311 * \\
(0.169)\end{array}$ & $\begin{array}{l}0.526^{*} \\
(0.277)\end{array}$ & $\begin{array}{l}0.349 * * \\
(0.113)\end{array}$ \\
\hline $\mathrm{R}^{2}$ & 0.923 & 0.935 & 0.954 & 0.925 & 0.915 & 0.932 \\
\hline
\end{tabular}

Among efficiency-driven countries, except for Model 4 (RQ), as expected, governance indicators have a negative impact on necessity entrepreneurship.

Tab.5 - Estimating opportunity entrepreneurship and economic growth (innovation-driven economies). Source: own research

\begin{tabular}{|c|c|c|c|c|c|c|}
\hline \multirow[b]{2}{*}{ Eq. (1). } & \multicolumn{6}{|l|}{ ODE } \\
\hline & $\begin{array}{l}\text { Model } 1 \\
\text { (VA) }\end{array}$ & $\begin{array}{l}\text { Model } 2 \\
\text { (PS) }\end{array}$ & $\begin{array}{l}\text { Model } 3 \\
\text { (GE) }\end{array}$ & $\begin{array}{l}\text { Model } 4 \\
\text { (RQ) }\end{array}$ & $\begin{array}{l}\text { Model } 5 \\
\text { (RL) }\end{array}$ & $\begin{array}{l}\text { Model } 6 \\
\text { (CC) }\end{array}$ \\
\hline (VA) & $\begin{array}{l}0.22^{* *} \\
(0.016) \\
\end{array}$ & & & & & \\
\hline (PS) & & $\begin{array}{l}0.241 * * * \\
(0.011)\end{array}$ & & & & \\
\hline (GE) & & & $\begin{array}{l}0.237 * * * \\
(0.027)\end{array}$ & & & \\
\hline (RQ) & & & & $\begin{array}{l}0.178^{* * *} \\
(0.034)\end{array}$ & & \\
\hline
\end{tabular}




\begin{tabular}{|c|c|c|c|c|c|c|}
\hline (RL) & & & & & $\begin{array}{l}0.197 * * * \\
(0.033)\end{array}$ & \\
\hline (CC) & & & & & & $\begin{array}{l}0.219^{* * *} \\
(0.048)\end{array}$ \\
\hline (GDP) & $\begin{array}{l}0.024 * * \\
(0.010)\end{array}$ & $\begin{array}{l}0.029 * * \\
(0.014)\end{array}$ & $\begin{array}{l}0.035^{* *} \\
(0.012)\end{array}$ & $\begin{array}{l}0.028^{* *} \\
(0.011)\end{array}$ & $\begin{array}{l}0.021 * * \\
(0.008)\end{array}$ & $\begin{array}{l}0.023^{* *} \\
(0.005)\end{array}$ \\
\hline (TB) & $\begin{array}{c}-0.42 * * \\
(0.146)\end{array}$ & $\begin{array}{c}-0.38^{* *} \\
(0.139)\end{array}$ & $\begin{array}{c}-0.32^{* *} \\
(0.187)\end{array}$ & $\begin{array}{c}-0.53^{* *} \\
(0.211)\end{array}$ & $\begin{array}{l}-0.58^{* *} \\
(0.279)\end{array}$ & $\begin{array}{l}-0.64 * * \\
(0.291)\end{array}$ \\
\hline$(\mathrm{FIN})$ & $\begin{array}{l}0.251^{* *} \\
(0.101)\end{array}$ & $\begin{array}{l}0.311^{* *} \\
(0.132)\end{array}$ & $\begin{array}{l}0.399 * * \\
(0.186)\end{array}$ & $\begin{array}{l}0.431^{*} \\
(0.202)\end{array}$ & $\begin{array}{l}0.401 * \\
(0.201)\end{array}$ & $\begin{array}{l}0.451 * \\
(0.233) \\
\end{array}$ \\
\hline $\mathrm{R}^{2}$ & 0.924 & 0.894 & 0.995 & 0.884 & 0.876 & 0.912 \\
\hline Eq. (2) & 1 & 2 & 3 & 4 & 5 & 6 \\
\hline ODE & $\begin{array}{l}0.05^{* * *} \\
(0.013)\end{array}$ & $\begin{array}{l}0.049 * * * \\
(0.012)\end{array}$ & $\begin{array}{l}0.048^{* * * *} \\
(0.016)\end{array}$ & $\begin{array}{l}0.039 * * \\
(0.011)\end{array}$ & $\begin{array}{l}0.038^{* *} \\
(0.015)\end{array}$ & $\begin{array}{l}0.051 * * \\
(0.019)\end{array}$ \\
\hline NDE & - & - & - & - & - & - \\
\hline (GCF) & $\begin{array}{l}0.12^{* * *} \\
(0.031)\end{array}$ & $\begin{array}{l}0.177 * * * \\
(0.021)\end{array}$ & $\begin{array}{l}0.182^{* * *} \\
(0.033)\end{array}$ & $\begin{array}{l}0.115^{* *} \\
(0.021)\end{array}$ & $\begin{array}{l}0.131 * * * \\
(0.041)\end{array}$ & $\begin{array}{l}0.18^{* * *} \\
(0.033)\end{array}$ \\
\hline (TR) & $\begin{array}{l}0.153 * \\
(0.072) \\
\end{array}$ & $\begin{array}{l}0.058^{* *} \\
(0.023)\end{array}$ & $\begin{array}{l}0.161 * * * \\
(0.035)\end{array}$ & $\begin{array}{l}0.164 * * \\
(0.061)\end{array}$ & $\begin{array}{l}0.152^{* * *} \\
(0.033)\end{array}$ & $\begin{array}{l}0.15^{* * *} \\
(0.03)\end{array}$ \\
\hline (INF) & $\begin{array}{l}-0.53^{* *} \\
(0.28)\end{array}$ & $\begin{array}{l}-0.62 * * \\
(0.34)\end{array}$ & $\begin{array}{c}-0.54^{*} \\
(0.34)\end{array}$ & $\begin{array}{l}-0.66^{* *} \\
(0.29)\end{array}$ & $\begin{array}{l}-0.75^{* *} \\
(0.30)\end{array}$ & $\begin{array}{l}-0.54^{* *} \\
(0.33)\end{array}$ \\
\hline$(\mathrm{GC})$ & $\begin{array}{l}0.527 * * \\
(0.24)\end{array}$ & $\begin{array}{l}0.45^{* *} \\
(0.20)\end{array}$ & $\begin{array}{l}0.36^{* *} \\
(0.13) \\
\end{array}$ & $\begin{array}{l}0.28^{* *} \\
(0.12)\end{array}$ & $\begin{array}{l}0.48^{* *} \\
(0.23)\end{array}$ & $\begin{array}{l}0.74 * * \\
(0.39) \\
\end{array}$ \\
\hline $\mathrm{R}^{2}$ & 0.929 & 0.934 & 0.957 & 0.946 & 0.932 & 0.944 \\
\hline
\end{tabular}

Among innovation-driven economies, the effect of governance on opportunity entrepreneurship is positive for all estimated models.

Tab.6 - Estimating necessity entrepreneurship and economic growth (innovation-driven economies). Source: own research

\begin{tabular}{|c|c|c|c|c|c|c|}
\hline \multirow[b]{2}{*}{ Eq. (1). } & \multicolumn{6}{|l|}{ NDE } \\
\hline & $\begin{array}{l}\text { Model } 1 \\
\text { (VA) }\end{array}$ & $\begin{array}{l}\text { Model } 2 \\
\text { (PS) }\end{array}$ & $\begin{array}{l}\text { Model } 3 \\
\text { (GE) }\end{array}$ & $\begin{array}{l}\text { Model } 4 \\
\text { (RQ) }\end{array}$ & $\begin{array}{l}\text { Model } 5 \\
(\mathrm{RL})\end{array}$ & $\begin{array}{l}\text { Model } 6 \\
\text { (CC) }\end{array}$ \\
\hline$(\mathrm{VA})$ & $\begin{array}{l}-0.22^{* *} \\
(0.011)\end{array}$ & & & & & \\
\hline (PS) & & $\begin{array}{l}-0.21 * * * \\
(0.023)\end{array}$ & & & & \\
\hline$(\mathrm{GE})$ & & & $\begin{array}{l}-0.231^{* * *} \\
(0.031)\end{array}$ & & & \\
\hline
\end{tabular}




\begin{tabular}{|c|c|c|c|c|c|c|}
\hline (RQ) & & & & $\begin{array}{l}-0.19 * * * \\
(0.021)\end{array}$ & & \\
\hline (RL) & & & & & $\begin{array}{l}-0.23 * * * \\
(0.031)\end{array}$ & \\
\hline (CC) & & & & & & $\begin{array}{l}-0.24 * * \\
(0.03)\end{array}$ \\
\hline (GDP) & $\begin{array}{l}0.0027 \\
(0.012) \\
\end{array}$ & $\begin{array}{l}0.0023 \\
(0.006)\end{array}$ & $\begin{array}{l}0.0039 \\
(0.013)\end{array}$ & $\begin{array}{l}0.0032 \\
(0.007)\end{array}$ & $\begin{array}{l}0.0021 \\
(0.009) \\
\end{array}$ & $\begin{array}{l}0.002 \\
(0.005) \\
\end{array}$ \\
\hline (TB) & $\begin{array}{l}-0.44 * * \\
(0.165)\end{array}$ & $\begin{array}{l}-0.34 * * \\
(0.121)\end{array}$ & $\begin{array}{c}-0.32 * * \\
(0.111)\end{array}$ & $\begin{array}{l}-0.59 * * \\
(0.233)\end{array}$ & $\begin{array}{l}-0.36 * * \\
(0.133)\end{array}$ & $\begin{array}{l}-0.61^{* *} \\
(0.25)\end{array}$ \\
\hline$(\mathrm{FIN})$ & $\begin{array}{l}0.254 * * \\
(0.121) \\
\end{array}$ & $\begin{array}{l}0.276^{* *} \\
(0.113)\end{array}$ & $\begin{array}{l}0.24^{* *} \\
(0.117) \\
\end{array}$ & $\begin{array}{l}0.39 * * * \\
(0.114)\end{array}$ & $\begin{array}{l}0.42 * * \\
(0.192) \\
\end{array}$ & $\begin{array}{l}0.51^{* *} \\
(0.20) \\
\end{array}$ \\
\hline $\mathrm{R}^{2}$ & 0.934 & 0.952 & 0.891 & 0.898 & 0.901 & 0.907 \\
\hline Eq. (2) & 1 & 2 & 3 & 4 & 5 & 6 \\
\hline ODE & - & - & - & - & - & - \\
\hline NDE & $\begin{array}{l}-0.069 \\
(0.043) \\
\end{array}$ & $\begin{array}{l}0.043 \\
(0.026)\end{array}$ & $\begin{array}{l}0.032 \\
(0.022)\end{array}$ & $\begin{array}{l}-0.041 \\
(0.029) \\
\end{array}$ & $\begin{array}{l}0.035 \\
(0.027) \\
\end{array}$ & $\begin{array}{l}0.039 \\
(0.024) \\
\end{array}$ \\
\hline (GCF) & $\begin{array}{l}0.148^{* *} \\
(0.031)\end{array}$ & $\begin{array}{l}0.139 * * \\
(0.047)\end{array}$ & $\begin{array}{l}0.18^{* * *} \\
(0.035)\end{array}$ & $\begin{array}{l}0.19^{* * *} \\
(0.038)\end{array}$ & $\begin{array}{l}0.166 * * * \\
(0.052)\end{array}$ & $\begin{array}{c}0.17 * * * \\
(0.036)\end{array}$ \\
\hline (TR) & $\begin{array}{l}0.036 \\
(0.021) \\
\end{array}$ & $\begin{array}{l}0.143 \\
(0.083)\end{array}$ & $\begin{array}{l}0.051 * * \\
(0.021)\end{array}$ & $\begin{array}{l}0.068 * \\
(0.036) \\
\end{array}$ & $\begin{array}{l}0.133 * * * \\
(0.043)\end{array}$ & $\begin{array}{l}0.12 * * * \\
(0.031) \\
\end{array}$ \\
\hline (INF) & $\begin{array}{l}-0.43^{*} \\
(0.23) \\
\end{array}$ & $\begin{array}{l}-0.58^{* *} \\
(0.29)\end{array}$ & $\begin{array}{l}-0.42^{*} \\
(0.18) \\
\end{array}$ & $\begin{array}{l}-0.54^{* *} \\
(0.20)\end{array}$ & $\begin{array}{l}-0.46^{* *} \\
(0.21)\end{array}$ & $\begin{array}{l}-0.34 * * \\
(0.12)\end{array}$ \\
\hline (GC) & $\begin{array}{l}0.49 * * * \\
(0.12)\end{array}$ & $\begin{array}{l}0.39 * * \\
(0.21)\end{array}$ & $\begin{array}{l}0.32 * * \\
(0.19)\end{array}$ & $\begin{array}{l}0.32^{* *} \\
(0.15)\end{array}$ & $\begin{array}{l}0.36^{* *} \\
(0.17)\end{array}$ & $\begin{array}{l}0.31^{* *} \\
(0.14)\end{array}$ \\
\hline $\mathrm{R}^{2}$ & 0.956 & 0.912 & 0.902 & 0.963 & 0.941 & 0.935 \\
\hline
\end{tabular}

Among innovation-driven economies, the effect of governance on necessity entrepreneurship is negative for all estimated models (Table 6).

Concerning the hypotheses testing, $\mathrm{H} 1$ proposes that governance has a positive influence on opportunity entrepreneurship. The results show a positive relationship between governance quality and opportunity entrepreneurship. Specifically, for voice and accountability (VA), our results show a positive connection with opportunity-driven entrepreneurs and a negative relationship with necessity entrepreneurship. The same results were found by Bjørnskov, \& Foss (2016), who argued that voice and accountability increase the set of opportunities for entrepreneurs. Regarding Political stability (PS), the results show that the positive impact of PS on ODE, in line with our expectations and those of Amorós et al. (2019), which documented that a high degree of political stability can provide a stable economic and business environment and encourage the establishment of new companies. Another variable that has a positive impact on ODE is government effectiveness (GE). Therefore, the improvement in the quality of services and public management, the independence from political pressure, and the improvement in 
the quality of government policies have encouraged opportunity-driven entrepreneurs, but it seems to hinder necessity-driven entrepreneurs (Acs et al., 2016; Rodríguez-Gulías et al., 2018). Furthermore, Regulatory quality (RQ) is directly proportional to opportunity entrepreneurship in line with the results of Bjørnskov \& Foss (2012) and Fuentelsaz et al. (2015). Regarding the rule of law (RL), similar researches also emphasize the close relationship between legal structure, property security and entrepreneurial activities (Aidis et al., 2012; Levie \& Autio, 2011). However, there may be an inverse relationship between the rule of law and entrepreneurship because many entrepreneurs have found alternative methods of contract enforcement independent of the legal system, and they may think that greater transparency is harmful. Finally, regarding control of corruption, a high degree of corruption can reduce the possibility of entrepreneurs engaging in high-growth activities because corruption can determine the uncertainty in the business environment (Berdiev \& Saunoris, 2018; Goel \& Saunoris, 2019; Dutta \& Sobel, 2016; Khyareh, 2017; Mohammadi et al., 2017). Therefore, H1 is supported by the data.

$\mathrm{H} 2$, which suggests that that governance has a negative influence on necessity entrepreneurship, is supported by our results. The results show a negative relationship between governance quality and necessity entrepreneurship. The similar results of the negative relation between the VA and NDE are consistent with the findings of Naudé (2010). Similarly, the negative relationship between political stability and NDE can be explained by the fact that political instability may cause some people to enter entrepreneurship for survival reasons. Regarding the negative impact of GE on ODE, the same results were found by Acs et al. (2016) and Rodríguez-Gulías et al. (2018). Regulatory quality (RQ) is negatively related to necessity entrepreneurship, only in innovation-driven countries. This negative effect can be explained by the fact that improving the quality of supervision will lead to creating new jobs or high-paying jobs (Bjørnskov \& Foss, 2012; Fuentelsaz et al., 2015; Nistotskaya \& Cingolani, 2016; Nyström, 2008).

$\mathrm{H} 3$ and $\mathrm{H} 4$ propose that economic growth is influenced positively and negatively by opportunitydriven and necessity-driven entrepreneurship, respectively, but their impact is differing by the level of economic development. Regarding the impact of entrepreneurship on economic growth, the results show that ODE is only positively correlated with economic growth in innovationdriven countries (Table 5). In contrast, NDE is negatively correlated with economic growth in factor-driven and efficiency-driven countries. This idea is supported by Bjørnskov \& Foss (2012) and Ghura et al. (2017). according to whom entrepreneurship related to innovation has a positive impact on economic performance. However, this result contradicts the findings of other studies such as Sautet (2013) which have found evidence that there is no relationship between opportunity entrepreneurship and economic growth in factor-driven and efficiencydriven countries. In addition, certain results show that opportunity entrepreneurship can bring economic growth more than can necessity-driven entrepreneurship. One possible reason for this is that the innovation-driven economy benefits greatly from the proliferation of high-growth expectation companies (Minniti \& Lévesque, 2010; Nikolaev et al., 2018; Vallierea \& Peterson 2009). High-growth entrepreneurs represent opportunity-driven entrepreneurs (Lecuna \& Chávez, 2018; Belda et al., 2018), as these entrepreneurs are always keen on growth and recognize the opportunities brought by innovative ideas. Meanwhile, necessity entrepreneurship activities, especially in factor- and efficiency-driven countries, avoid growth. Therefore, different 
country groups have different entrepreneurial influences on economic growth according to their development stages. In this regard, the study by Wennekers et al. (2008) shows that there seems to be a U-shaped relationship between the level of economic development and the rate of entrepreneurship. A study by Van Stel et al. (2005) shows that entrepreneurial activities have a positive impact on the economic growth of high-developed countries, but a negative impact on developing countries. Although Wennekers et al. (2008) have found that developing countries often possess more necessity entrepreneurship, U-shaped tables have been determined.

Regarding the control variables, for all the countries in the sample several indicators emerge that have an important impact on economic growth: gross capital formation (GFC), trade (TR), inflation (INF), and government consumption (GC). Regarding gross capital formation, the estimates showed a positive and significant impact on the economic growth for the entire sample, with the result indicating that GFC would make a significant contribution to economic growth. The positive impact of government expenditure on economic growth indicates that expenditure is an important determinant of growth. These findings are similar to those of Amaghouss \& Ibourk (2013) and Simionescu et al. (2017). Regarding economic openness, our results show a positive impact on economic growth. Idris et al. (2018) pointed out a positive impact of economic openness on developing countries, and the researchers emphasize that developing countries are more open to trade to promote growth than are developed countries. In all models, the inflation rate has shown a negative impact on growth, indicating that a higher inflation rate in these countries determines a slowdown in economic growth. According to Chambers \& Munemo (2017), the time required to start a new business in their entire sample was negative and significant. Thus, fewer costs to starting a business would be related to higher entrepreneurial activity. Finally, while financial development shows the expected signs, in factordriven countries this coefficient is not significant in some models.

\section{CONCLUSION}

This paper describes the possible impact of opportunity-driven and necessity-driven entrepreneurship on economic growth at the national level at different economic stages of the country. We aim to determine the possible role of the governance quality entrepreneurshipgrowth nexus using the "Coleman Bathtub" model to explain the relationship between governance quality, entrepreneurial activity and economic growth. The empirical results show that the impact of entrepreneurship on economic growth varies with the stage of economic development. According to the results, poor governance quality can stimulate NDE and hinder ODE. The negative relationship between governance and ODE can be explained by the low quality of governance, which leads individuals merely to seek survival due to a lack of employment options. In other words, the negative link between governance and the informal economy can be explained by the fact that poor governance quality will lead to the growth of the informal economy since individuals can and, in fact, must participate in entrepreneurial activities in the informal sector. Similarly, the results indicate that the impact of entrepreneurship on economic growth in factor, efficiency, and innovation-driven countries may be inconsistent. Therefore, the authors have found that the level of entrepreneurial activity will be significantly affected by the quality of governance, the impact of which may vary depending on the motivation (opportunity 
or necessity) of individual entrepreneurs. Therefore, we reveal that governance quality has a significant positive impact on opportunity (productive) entrepreneurial activities and a negative effect on the rate of necessity (non-productive) entrepreneurship. This means that higher levels of governance quality often favor opportunity entrepreneurs and encourage them to start new businesses. Necessity entrepreneurs are negatively correlated with governance quality indicators. Therefore, we believe that the results of this empirical research can attract decisionmakers, who should focus on identifying and implementing the most appropriate measures to improve the quality of governance, which in turn would promote entrepreneurship and support entrepreneurial development.

One of the main findings of this study is that opportunity entrepreneurship will only promote economic growth in innovation-driven countries, but has no effect on factor- and efficiencydriven countries (Van Stell et al., 2005; Sautte, 2013). These findings indicate that the policies aimed at encouraging entrepreneurship in innovation-driven countries are not effective in factor- and efficiency-driven countries (Acs et al., 2016; Mason \& Brown, 2013). Meanwhile, economic growth does not seem to contribute to necessity entrepreneurship in all three groups of countries. In addition, the survey results indicate that the quality of governance is an important factor in promoting entrepreneurial activity and subsequent economic growth in all three country groups. These findings support previous research findings on entrepreneurship, institutions, and economic growth (Bosma et al., 2018). The results also have policy implications for promoting the importance of entrepreneurship in encouraging economic growth.

These results highlight an important issue: Entrepreneurship alone is not enough to promote economic growth. In addition, it is more important to maintain high-quality institutions (regulatory quality, voice and accountability, political stability, etc.), which will have a significant impact on entrepreneurship. Therefore, the policy focus should shift from increasing the number of entrepreneurs to improving the quality of governance. In addition, factor- and efficiencydriven countries must organize their policies appropriately and remove unnecessary barriers and controls that hinder commercial activities. They need to protect and promote property rights and develop strategies to support the creativity and efficiency of the private sector. The quality of governance and entrepreneurship can help improve the economic and social conditions of these countries. Better governance will create an essential set of institutions that can increase the productivity of human capital and ultimately improve economic growth. Based on these results, regulatory agencies, policy measures and international organizations should strive to promote greater transparency and better accountability, the strong rule of law and judicial enforcement, better regulatory quality, and essential control over corruption. Therefore, regulatory agencies, policy measures, and international organizations need to formulate more consistent policies and reconsider corporate scale and national-level governance indicators to improve the corporate environment and activities.

Although this research has allowed us to determine strong empirical results, future research may focus on different types of variables for entrepreneurship (for example, formal and informal entrepreneurship; Schumpeterian and Kirzner entrepreneurship). In addition, future research may use various institutional variables such as economic freedom or market-friendly institutions. It should be noted that certain limitations of this study may be related to the model used in terms 
of the results of the investigation. The first limitation concerns the results of model estimation, which proved valid only for the country examined and may only be valid for the period under consideration. As a result, the estimated value may change, as other variables can affect the level of business activities. The second limitation is the lack of data for an extended time.

\section{References}

1. Acs, Z. J., Desai, S., \& Hessels, J. (2008). Entrepreneurship, economic development and institutions. Small business economics, 31 (3), 219-234. http://dx.doi.org/10.1007/s11187-008$9135-9$

2. Acs, Z. J., Estrin, S., Mickiewicz, T., \& Szerb, L. (2018). Entrepreneurship, institutional economics, and economic growth: an ecosystem perspective. Small Business Economics, 51 (2), 501-514. http://dx.doi.org/10.1007/s11187-018-0013-9

3. Acs, Z., Åstebro, T., Audretsch, D., \& Robinson, D. T. (2016). Public policy to promote entrepreneurship: a call to arms. Small Business Economics, 47 (1), 35-51. http://dx.doi. org/10.1007/s11187-016-9712-2

4. Aidis, R., Estrin, S., \& Mickiewicz, T. M. (2012). Size matters: entrepreneurial entry and government. Small Business Economics, 39 (1), 119-139. http://dx.doi.org/10.1007/s11187-0109299-y

5. Amaghouss, J., \& Ibourk, A. (2013). Entrepreneurial Activities, Innovation and Economic Growth: The Role of Cyclical Factors: Evidence from OECD Countries for the Period 20012009. International Business Research, 6 (1), 153-162. http://dx.doi.org/10.5539/ibr.v6n1p153

6. Amorós, J. E., \& Stenholm, P. (2014). The Influence of the Quality of Government Institutions on Entrepreneurial Motivation: Exploring the Variance across Countries. Working Paper No. 14/1). http://dx.doi.org/10.2139/ssrn.2538994

7. Amorós, J. E., Borraz, F., \& Veiga, L. (2016). Entrepreneurship and socioeconomic indicators in Latin America. Latin American Research Review, 51 (4), 186-201. http://dx.doi.org/10.1353/ lar.2016.0055

8. Amorós, J. E., Ciravegna, L., Mandakovic, V., \& Stenholm, P. (2019). Necessity or opportunity? The effects of State fragility and economic development on entrepreneurial efforts. Entrepreneurship Theory and Practice, 43 (4), 725-750. http://dx.doi. $\operatorname{org} / 10.1177 / 1042258717736857$

9. Aparicio, S., Urbano, D., \& Audretsch, D. (2016). Institutional factors, opportunity entrepreneurship and economic growth: Panel data evidence. Technological Forecasting and Social Change, 102, 45-61. http://dx.doi.org/10.1016/j.techfore.2015.04.006

10. Audretsch, D. (2012). Entrepreneurship research. Management Decision, 50 (5), 755-764. http:// dx.doi.org/10.1108/00251741211227384

11. Belda, P. R., \& Cabrer-Borrás, B. (2018). Necessity and opportunity entrepreneurs: Survival factors. International Entrepreneurship and Management Journal, 14 (2), 249-264. http://dx.doi. org/10.1007/s11365-018-0504-9

12. Belitski, M., Chowdhury, F., \& Desai, S. (2016). Taxes, corruption, and entry. Small Business Economics, 47 (1), 201-216. http://dx.doi.org/10.1007/s11187-016-9724-y 
13. Berdiev, A. N., \& Saunoris, J. W. (2018). Corruption and entrepreneurship: Cross-country evidence from formal and informal sectors. Southern Economic Journal, 84 (3), 831-848. http:// dx.doi.org/10.1002/soej.12250

14. Bjørnskov, C., \& Foss, N. (2012). How strategic entrepreneurship and the institutional context drive economic growth. Strategic Entrepreneurship Journal, 7 (1), 50-69. http://dx.doi. $\operatorname{org} / 10.1002 /$ sej. 1148

15. Bjørnskov, C., \& Foss, N. J. (2016). Institutions, entrepreneurship, and economic growth: what do we know and what do we still need to know? Academy of Management Perspectives, 30 (3), 292-315. http://dx.doi.org/10.5465/amp.2015.0135

16. Bosma, N., Sanders, M., \& Stam, E. (2018). Institutions, entrepreneurship, and economic growth in Europe. Small Business Economics, 51 (2), 483-499. http://dx.doi.org/10.1007/s11187018-0012-x

17. Boudreaux, C. J., \& Nikolaev, B. (2019). Capital is not enough: opportunity entrepreneurship and formal institutions. Small Business Economics, 53 (3), 709-738. http://dx.doi.org/10.1007/ s11187-018-0068-7

18. Boudreaux, C. J., Nikolaev, B. N., \& Holcombe, R. G. (2018). Corruption and destructive entrepreneurship. Small Business Economics, 51 (1), 181-202. http://dx.doi.org/10.1007/s11187017-9927-x

19. Carree, M. A., \& Thurik, A. R. (2010). The impact of entrepreneurship on economic growth. In Handbook of entrepreneurship research, 557-594.. http://dx.doi.org/10.1007/0-387-245197_17

20. Chambers, D., \& Munemo, J. (2017). The Impact of Regulations and Institutional Quality on Entrepreneurship. Mercatus Working Paper. http://dx.doi.org/10.2139/ssrn.3066312

21. Coleman, J. S. (1990). Foundations of Social Theory. Cambridge, MA: Belknap Press of Harvard University Press.

22. Debus, M., Tosun, J., \& Maxeiner, M. (2017). Support for Policies on Entrepreneurship and Self-Employment among Parties and Coalition Governments. Politics \& Policy, 45 (3), 338-371. http://dx.doi.org/10.1111/polp.12205

23. Doran, J., McCarthy, N., \& O’Connor, M. (2018). The role of entrepreneurship in stimulating economic growth in developed and developing countries. Cogent Economics \& Finance, 6 (1), 1442093. http://dx.doi.org/10.1080/23322039.2018.1442093

24. Dutta, N., \& Sobel, R. (2016). Does corruption ever help entrepreneurship? Small Business Economics, 47 (1), 179-199. http://dx.doi.org/10.1007/s11187-016-9728-7

25. Dvouletý, O. (2018). How to analyses determinants of entrepreneurship and self-employment at the country level? A methodological contribution. Journal of Business Venturing Insights, 9, 92-99. http://dx.doi.org/10.1016/j.jbvi.2018.03.002

26. Estrin, S., Korosteleva, J., \& Mickiewicz, T. (2013). Which institutions encourage entrepreneurial growth aspirations? Journal of business venturing, 28 (4), 564-580. http://dx.doi. org/10.1016/j.jbusvent.2012.05.001

27. Franke, G. R., \& Richey, R. G. (2010). Improving generalizations from multi-country comparisons in international business research. Journal of International Business Studies, 41 (8), 
1275-1293. http://dx.doi.org/10.1057/jibs.2010.21

28. Fredström, A., Peltonen, J., \& Wincent, J. (2020). A country-level institutional perspective on entrepreneurship productivity: The effects of informal economy and regulation. Journal of Business Venturing, 106002. http://dx.doi.org/10.1016/j.jbusvent.2020.106002

29. Fuentelsaz, L., González, C., Maícas, J. P., \& Montero, J. (2015). How different formal institutions affect opportunity and necessity entrepreneurship. BRQ Business Research Quarterly, 18 (4), 246-258. http://dx.doi.org/10.1016/j.brq.2015.02.001

30. Ghura, H., Li, X., \& Harraf, A. (2017). Moderating relationship of institutions for opportunity entrepreneurship and economic development. World Journal of Entrepreneurship, Management and Sustainable Development, 13 (4), 350-374. http://dx.doi.org/10.1108/WJEMSD-06-2017-0031

31. Global Entrepreneurship Monitor datasets. (2019). Retrieved from https://www. gemconsortium.org/data/sets

32. Goel, R. K., \& Saunoris, J. W. (2019). International corruption and its impacts across entrepreneurship types. Managerial and Decision Economics, 40 (5), 475-487. http://dx.doi. $\operatorname{org} / 10.1002 /$ mde.3017

33. Huynh, K. P., \& Jacho-Chávez, D. T. (2009). Growth and governance: A nonparametric analysis. Journal of Comparative Economics, 37 (1), 121-143. http://dx.doi.org/10.1016/j. jce.2008.08.003

34. Idris, J., Yusop, Z.; Habibullah, M.S.; Chin, L. (2018). Openness and Economic Growth in Developing and OECD Countries. International Journal of Economics \& Management, 12 (2), 693-702. http://dx.doi.org/10.13140/RG.2.2.26294.14404

35. Jimenez, A., Puche-Regaliza, J. C., \& Jimenez, J. A. (2015). Institutional quality and entrepreneurship: the role of political discretionality and corruption. In Academy of Management Proceedings, 2015 (1), 15569. http://dx.doi.org/10.5465/ambpp.2015.15569abstract

36. Kaufmann, D., Kraay, A., \& Mastruzzi, M. (2017). The Worldwide Governance Indicators: Methodology and Analytical Issues. Hague Journal on the Rule of Law, 3 (2), 220-246. http:// dx.doi.org/10.1017/S1876404511200046

37. Kim, P. H., Wennberg, K., \& Croidieu, G. (2016). Untapped riches of meso-level applications in multilevel entrepreneurship mechanisms. Academy of Management Perspectives, 30 (3), 273-291. http://dx.doi.org/10.5465/amp.2015.0137

38. Larroulet, C., \& Couyoumdjian, J. (2009). Entrepreneurship and Growth: A Latin American Paradox? The Independent Review, 14 (1), 81-100.

39. Lecuna, A., \& Chávez, R. (2018). Entrepreneurship and Weak Institutions in Latin America. The Journal of Private Enterprise, 33 (3), 25-47.

40. Lepojevic, V., Djukic, M. I., \& Mladenovic, J. (2016). Entrepreneurship and economic development: A comparative analysis of developed and developing countries. Facta Universitatis, Series: Economics and Organization, 13 (1), 17-29.

41. Levie, J., \& Autio, E. (2011). Regulatory burden, rule of law, and entry of strategic entrepreneurs: An international panel study. Journal of Management Studies, 48(6), 1392-1419. http://dx.doi.org/10.1111/j.1467-6486.2010.01006.x 
42. Liñán, F., \& Fernandez-Serrano, J. (2014). National culture, entrepreneurship and economic development: different patterns across the European Union. Small Business Economics, 42 (4), 685-701. http://dx.doi.org/10.1007/s11187-013-9520-x

43. Mason, C., \& Brown, R. (2013). Creating good public policy to support high-growth firms. Small Business Economics, 40 (2), 211-225. http://dx.doi.org/10.1007/s11187-011-9369-9

44. Minniti, M., \& Lévesque, M. (2010). Entrepreneurial types and economic growth. Journal of Business Venturing, 25 (3), 305-314. http://dx.doi.org/10.1016/j.jbusvent.2008.10.002

45. Mohammadi Khyareh, M. (2017). Institutions and entrepreneurship: the mediating role of corruption. World Journal of Entrepreneurship, Management and Sustainable Development, 13 (3), 262-282. https://doi.org/10.1108/WJEMSD-09-2016-0045

46. Naudé, W. (2010). Entrepreneurship, developing countries, and development economics: new approaches and insights. Small business economics, 34 (1), 1. http://dx.doi.org/10.1007/s11187-0099198-2

47. Nikolaev, B. N., Boudreaux, C. J., \& Palich, L. (2018). Cross-country determinants of early-stage necessity and opportunity-motivated entrepreneurship: accounting for model uncertainty. Journal of Small Business Management, 56, 243-280. http://dx.doi.org/10.1111/ jsbm. 12400

48. Nistotskaya, M., \& Cingolani, L. (2016). Bureaucratic structure, regulatory quality, and entrepreneurship in a comparative perspective: Cross-sectional and panel data evidence. Journal of Public Administration Research and Theory, 26 (3), 519-534. http://dx.doi.org/10.1093/ jopart/muv026

49. Nyström, K. (2008). The institutions of economic freedom and entrepreneurship: evidence from panel data. Public Choice, 136 (2), 269-282. http://dx.doi.org/10.1007/s11127-008-9295-9

50. Rodríguez-Gulías, M. J., de Sousa Gabriel, V. M., \& Rodeiro-Pazos, D. (2018). Effects of governance on entrepreneurship: European Union vs. non-European Union. Competitiveness Review: An International Business Journal, 28 (1), 43-57. http://dx.doi.org/10.1108/CR-06-20160035

51. Sautet, F. (2013). Local and systemic entrepreneurship: Solving the puzzle of entrepreneurship and economic development. Entrepreneurship Theory and Practice, 37 (2), 387-402. http://dx.doi. $\operatorname{org} / 10.1111 / j .1540-6520.2011 .00469 . x$

52. Simionescu, M., Lazanyi, K., Sopkova, G., Dobeš, K., \& Balcerzak, A. P. (2017). Determinants of economic growth in V4 countries and Romania. Journal of Competitiveness, 9 (1), 103-116. http://dx.doi.org/10.7441/joc.2017.01.07

53. Simón-Moya, V., Revuelto-Taboada, L., \& Guerrero, R. F. (2014). Institutional and economic drivers of entrepreneurship: An international perspective. Journal of Business Research, 67 (5), 715-721. http://dx.doi.org/10.1016/j.jbusres.2013.11.033

54. Stam, E., Hartog, C., Van Stel, A., \& Thurik, R. (2011). Ambitious entrepreneurship, high-growth firms and macroeconomic growth. The dynamics of entrepreneurship: Evidence from global entrepreneurship monitor data, 231-249. http://dx.doi.org/10.1093/acprof:o so/9780199580866.003.0011

55. Stenholm, P., Acs, Z. J., \& Wuebker, R. (2013). Exploring country-level institutional 
arrangements on the rate and type of entrepreneurial activity. Journal of Business Venturing, 28 (1), 176-193. http://dx.doi.org/10.1016/j.jbusvent.2011.11.002

56. Urbano, D., \& Aparicio, S. (2016). Entrepreneurship capital types and economic growth: International evidence. Technological Forecasting and Social Change, 102, 34-44. http://dx.doi. org/10.1016/j.techfore.2015.02.018

57. Urbano, D., Aparicio, S., \& Audretsch, D. (2019). Twenty-five years of research on institutions, entrepreneurship, and economic growth: what has been learned? Small Business Economics, 53 (1), 21-49. http://dx.doi.org/10.1007/s11187-018-0038-0

58. Valliere, D., \& Peterson, R. (2009). Entrepreneurship and economic growth: Evidence from emerging and developed countries. Entrepreneurship \& Regional Development, 21 (5), 459-480. http://dx.doi.org/10.1080/08985620802332723

59. Van Stel, A., Carree, M., \& Thurik, R. (2005). The effect of entrepreneurial activity on national economic growth. Small business economics, 24 (3), 311-321. https://doi.org/10.1007/ s11187-005-1996-6

60. Wennekers, S., Van Wennekers, A., Thurik, R., \& Reynolds, P. (2008). Nascent entrepreneurship and the level of economic development. Small business economics, 24 (3), 293-309. http://dx.doi.org/10.1007/s11187-007-9066-x

61. Youssef, A. B., Boubaker, S., \& Omri, A. (2018). Entrepreneurship and sustainability: The need for innovative and institutional solutions. Technological Forecasting and Social Change, 129, 232-241. https://doi.org/10.1016/j.techfore.2017.11.003

\section{Contact information}

prof. Mohsen Mohammadi Khyareh, Ph.D.

Gonbad Kavous University

Humanities \& Physical Education

Department (Institute): Administrative and Economic Science

Iran

E-mail:m.mohamadi@gonbad.ac.ir;m.mohamadi@ut.ac.ir

ORCID: 0000-0003-3977-0929

prof. Hadi Amini, Ph.D.

Gonbad Kavous University

Humanities \& Physical Education

Department (Institute): Administrative and Economic Science

Iran

E-mail:amini@gonbad.ac.ir

ORCID: 0000-0001-8002-8182 


\section{Appendix 1:}

Tab. A - List of sample countries by development stages. Source: GEM database, 2019

\begin{tabular}{|l|l|l|}
\hline $\begin{array}{l}\text { Factor-driven } \\
\text { Economy }\end{array}$ & $\begin{array}{l}\text { Efficiency-driven } \\
\text { Economy }\end{array}$ & $\begin{array}{l}\text { Innovation-driven } \\
\text { Economy }\end{array}$ \\
\hline Angola & Argentina & Australia \\
\hline Barbados & Bosnia & Belgium \\
\hline Botswana & Brazil & Canada \\
\hline Burkina Faso & Chile & Croatia \\
\hline Cameroon & China & Estonia \\
\hline Ghana & Ecuador & Finland \\
\hline India & Egypt & France \\
\hline Kazakhstan & Guatemala & Germany \\
\hline Lebanon & Indonesia & Greece \\
\hline Morocco & Iran & Hungary \\
\hline Pakistan & Jamaica & Ireland \\
\hline Trinidad and Tobago & Latvia & Israel \\
\hline Tunisia & Luxembourg & Italy \\
\hline Uganda & Macedonia & Japan \\
\hline Zambia & Mexico & Malaysia \\
\hline & Panama & Norway \\
\hline & Peru & Poland \\
\hline & Puerto Rico & Portugal \\
\hline & Russia & Slovakia \\
\hline & South Africa & Slovenia \\
\hline & Urugiland & South Korea \\
\hline & & Spain \\
\hline & & Sweden \\
\hline & Switzerland \\
\hline & & United Kingdom \\
\hline & & United States \\
\hline & & \\
\hline & & \\
\hline
\end{tabular}

